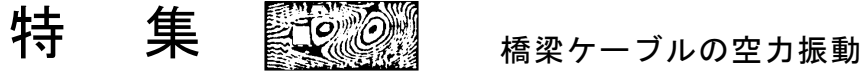

\section{大型傾斜ケーブル模型を用いた空力振動現象に関する屋外動態観測 \\ Field Observation on Wind-induced Vibrations of \\ Large-scale Inclined Cable Model}

\author{
八木知已 ${ }^{* 1}$ 松本 勝*2
}

Tomomi YAGI, Masaru MATSUMOTO

\section{1.はじめに}

斜張橋ケーブルの空力振動現象には，渦励振，レイ ンバイブレーション, ドライステートギャロッピング等 が考えらえるが，通常工学的に問題となるのは，降雨時 に観測されるレインバイブレーションとケーブル表面が 乾燥している状態で発生するドライステートギャロッピ ングである。一般に, レインバイブレーションとは, 降 雨時に，風下に向かってケーブルの高さが低くなってい く「下り勾配」を持つケーブルの表面に水路が形成され ることによって発現すると考えられている ${ }^{1) 。 た た ゙ し ， ~}$ 実橋で観測される場合には，水路の形成を確認すること は困難であり，降雨時の振動を全てレインバイブレーシ ヨンと呼んでいることが多い。一方，水路が形成されて いない状況で発生するドライステートギャロッピングは, 雨なし振動とも呼ばれるが, レインバイブレーションに 比べて観測事例は少ない，一般に, 臨界レイノルズ数域 に達するような高風速下で発生すると考えられているが 2-5), 未だ不明な点も多く残されている。また, 降雨下に おいても, 水路が形成されていなければ, ドライステー トギャロッピングで振動している可能性もある。従って, 降水量, 風向, 風速といった気象データとケーブルの応 答データからだけでは, 振動メカニズムを考察すること
は実際上, 困難なことが多い。実橋の観測データからは, 簡単に分類できないような振動事例が観測されることも 多々あり，全ての観測事例を未だ説明できていないのが 現状である。

典型的なレインバイブレーションの観測事例としては, 名港西大橋ので最初に観測されて以来，荒津大橋 7)，天 保山大橋 ${ }^{8)}$ の他，数々の斜張橋で観測されている。天保 山大橋では, 風速 9 10m/s で倍振幅 $237 \mathrm{~cm}$ にもぶ大振 幅振動が観測されており，このような条件下でケーブル 表面に水路が形成されて，レインバイブレーションが発 生したのかどうか，疑問の声もある。一方で，ドライス テートギャロッピングと思われる実橋での振動事例は数 少ないが，可能性のある振動事例を写真 1 に示寸9)。台 風通過時に，地面に定着されたケーブルが大振幅振動を 発生し, 橋梁の高欄, フェアリングが損傷した事例であ る。目撃者の証言によると，振動時は雨が止んでいたと のことであり，ドライステートギャロッピングの疑いが ある。

以上のように, 限られた実橋の観測事例からだけでは, メカニズムの解明が容易ではない。また風洞実験におい ては, 数々の研究成果が上がっているが, 実際の斜張橋 ケーブルに比べて，アスペクト比の極めて小さな模型を

* 1 京都大学大学院工学研究科社会基盤工学専攻 准教授

Associate Professor, Department of Civil and Earth Resources Engineering, Kyoto University * 2 京都大学 名誉教授

Professor Emeritus, Kyoto University 
使用している事，さらには風洞内で模型を傾斜させると 模型端部（風洞壁）による影響が実験結果に現れるとい った問題があり，実橋の観測事例を完全に説明するには 至っていない。そこで筆者等は，実橋の観測事例と風洞 実験結果を関連付る目的で，2000 年から 2003 年にかけ て, 大型傾斜ケーブル模型を作製し, 屋外観測を行った 10-14)。その当時の結果を以下に報告する。
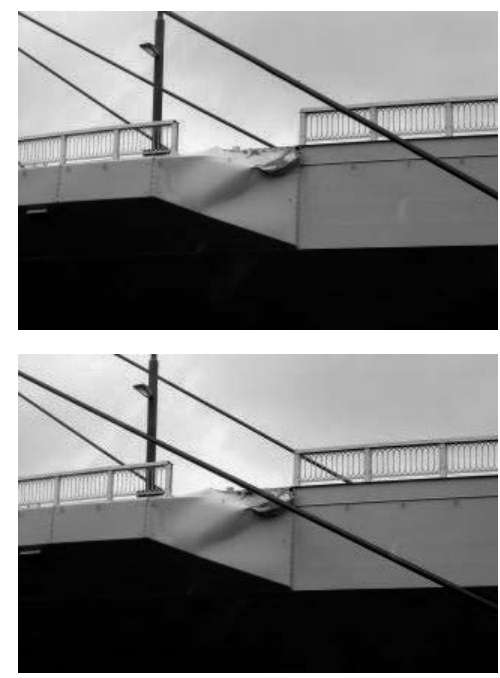

写真 1 実橋ケーブルの振動事例 ${ }^{9)}$

2. 観測概要

2. 1 大型ケーブル模型概要

大型ケーブル模型の設置ならびに観測は，和歌山県潮 岬に所在する京都大学防災研究所附属潮岬風力実験所の 敷地内（海抜 $50 \mathrm{~m}$ ) で行った。この地域は台風および季 節風の影響で一年を通じ比較的風が強く，ケーブル模型 の振動観測に適していると考えられるが，周辺環境の影
響で乱流強度が大きいことには注意を要する。長さ $30 \mathrm{~m}$ の大型ケーブル模型を設置するために, 現地に高さ $23.5 \mathrm{~m}$ の塔を建設し, 地表面高さ $21 \mathrm{~m}$ の位置に模型上端 を固定し，模型下端は地表面付近に定着させた（写真 2 参照)。模型上端と下端を結ぶ線と地表面がなす鉛直角 $\alpha$ はおよそ 45である。大型ケーブル模型は塔を西側にし て東西方向に張られている。

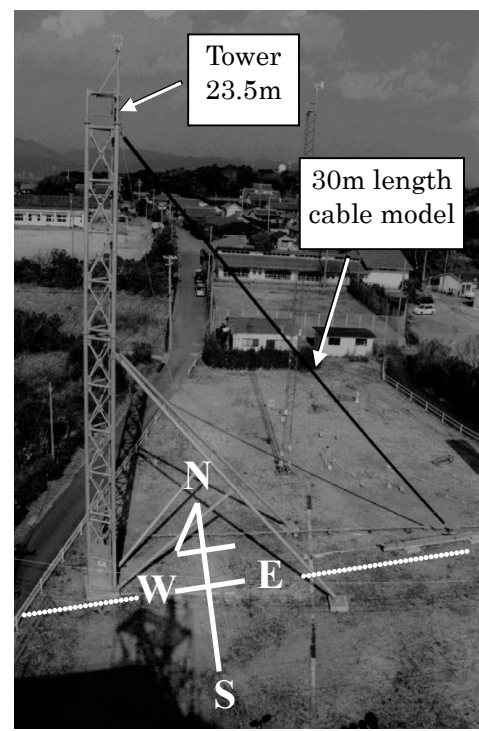

写真 2 大型ケーブル模型設置状況

ケーブル模型の径は，実際の斜張橋に使用されている ケーブル径とほぼ同等のものとし, ケーブル模型の表面 も実橋に合わせてポリエチレン管（PE 管）で被覆した。 ただし，空力振動が励起されやすいように，実橋ケーブ ルに比べて, 構造減衰ならびに単位長さ重量を小さくし ている。本研究では，観測期間中，3 種類のケーブル模

表1 ケーブル模型の構造諸元 $\quad(f$ : 固有振動数, $\delta$ : 対数減衰率, $S c$ : スクルートン数 $)$

\begin{tabular}{|c|c|c|c|c|c|c|c|c|c|}
\hline \multirow{2}{*}{\multicolumn{2}{|c|}{ Cable length $L(\mathrm{~m})$}} & \multicolumn{2}{|l|}{ Type A } & \multicolumn{2}{|l|}{ Type B } & Type C & & & \\
\hline & & 30 & & 30 & & 30 & & & \\
\hline Cable dian & $\operatorname{er} D(\mathrm{~m})$ & 0.11 & & 0.16 & & 0.15 & & & \\
\hline \multicolumn{2}{|c|}{ Mass/length $m(\mathrm{~kg} / \mathrm{m})$} & 6.06 & & 11.46 & & 6.50 & & & \\
\hline & $\begin{array}{l}\text { Type A } \\
f(\mathrm{~Hz})\end{array}$ & $\delta$ & Sc & $\begin{array}{l}\text { Type B } \\
f(\mathrm{~Hz})\end{array}$ & $\delta$ & Sc & $\begin{array}{l}\text { Type C } \\
f(\mathrm{~Hz})\end{array}$ & $\delta$ & $S c$ \\
\hline \multicolumn{10}{|l|}{ Out-plane } \\
\hline $1^{\text {st }}$ mode & 1.07 & - & - & 0.78 & 0.01750 & 13.06 & 0.98 & 0.03934 & 18.57 \\
\hline $2^{\text {nd }}$ mode & 2.25 & - & - & 1.61 & 0.01420 & 10.30 & 2.34 & 0.01702 & 8.03 \\
\hline $3^{\text {rd }}$ mode & 3.81 & - & - & 2.44 & 0.00807 & 6.02 & 4.59 & 0.00351 & 1.66 \\
\hline $4^{\text {th }}$ mode & 5.57 & - & - & 3.22 & - & - & 7.42 & - & - \\
\hline \multicolumn{10}{|l|}{ In-plane } \\
\hline $1^{\text {st }}$ mode & 1.37 & 0.00790 & 6.53 & 0.93 & 0.03750 & 27.98 & 1.46 & 0.02782 & 13.13 \\
\hline $2^{\text {nd }}$ mode & 2.44 & 0.00450 & 3.72 & 1.61 & 0.00846 & 6.31 & 2.64 & 0.00937 & 4.42 \\
\hline $3^{\text {rd }}$ mode & 4.00 & - & - & 2.44 & 0.00607 & 4.53 & 4.88 & - & - \\
\hline $4^{\text {th }}$ mode & 5.96 & - & - & 3.22 & 0.00912 & 6.80 & 7.81 & - & - \\
\hline
\end{tabular}


型を使用した。以下にその特徴を列記すると共に構造諸 元を表 1 に示す。

(1) ケーブル模型 A

本模型は, 2000 年 11 月から 2001 年 8 月にかけて設置 されたもので, アルミニウム管（直径 $100 \mathrm{~mm}$, 長さ $4000 \mathrm{~mm}$, 厚さ $5 \mathrm{~mm} ） 7$ 本と, 同様の構造のアルミニウ 么管（直径 $100 \mathrm{~mm}$, 長さ $2000 \mathrm{~mm}$, 厚さ $5 \mathrm{~mm}$ ） 1 本を連 結し，PE管（厚さ $5 \mathrm{~mm}$ ) で被覆した中空円柱構造の模 型である。ケーブル模型の径は $0.11 \mathrm{~m}$, 全長は $30 \mathrm{~m}$, 単 位長さ質量は $6.06 \mathrm{~kg} / \mathrm{m}$ である。構造減衰が比較的小さい のが特徴である。

(2) ケーブル模型 B

本模型は, 2001 年 8 月から 2002 年 10 月にかけて設置 されたものであり, アルミニウム管（直径 $150 \mathrm{~mm}$, 長さ

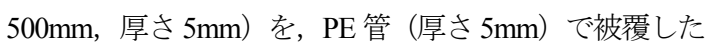
中空円筒エレメント 58 個を外形材として, 心材のワイヤ 一ケーブルに取り付けたものである。ケーブル模型の径 は $0.16 \mathrm{~m}$, 全長は $30 \mathrm{~m}$, 単位長さ質量は $11.46 \mathrm{~kg} / \mathrm{m}$ であ る。このような構造にすることで, ケーブル模型の動特 性に対するアルミニウム管の曲げ剛性の影響が小さくな り, 比較的, 弦の振動特性に近くなる。なお, 各エレメ ント間の隙間は防食用ポリ塩化ビニル粘着テープで埋め ている。

\section{(3) ケーブル模型 C}

本模型は, 2002 年 11 月から観測終了まで設置したも のであり,アルミニウム管 (直径 $150 \mathrm{~mm}$, 長さ $4000 \mathrm{~mm}$,

厚さ $5 \mathrm{~mm}$ ) 7 本と, 同様の構造のアルミニウム管（直径 $150 \mathrm{~mm}$ ，長さ $2000 \mathrm{~mm}$ ，厚さ $5 \mathrm{~mm} ） 1$ 本を連結した模型 であり, ケーブル A と同様の構造である。ただし, 模型 を軽量化するために, 表面を PE 管では被覆せず, ラッ カーにフラットベースを混ぜた塗装を施すことで PE 管 と同様の撥水性を持たせている。ケーブル模型の径は $0.15 \mathrm{~m}$, 全長は $30 \mathrm{~m}$, 単位長さ質量は $6.5 \mathrm{~kg} / \mathrm{m}$ である。た だし, 本報告には当模型を用いた計測結果は省略する ${ }^{13)}$.

表 1 より, 実橋ケーブルと比較して, 何れのケーブル 模型も $S c$ 数が小さくなっている. また, ケーブル模型 $\mathrm{A}$ およびCでは, 各モードの固有振動数が 1 次モードの倍 数になっておらず, これはアルミニウム 管の曲げ剛性の効果が現れているものと 考えられる。一方,ケーブル模型Bでは, 比較的弦に近い構造特性を示しているが, 模型質量が大きいため, 固有振動数は小 さくなっている。なお, 面内振動とはケ ーブル模型と塔を含んだ面内での振動で
あり，面外振動とはケーブル模型と塔が作る面に垂直な 方向の振動と定義する。

\section{2 観測方法}

大型ケーブル模型の振動計測では, 地表面から高さ $2.8 \mathrm{~m}$ の位置の模型表面に加速度計を設置し, ケーブル面 内及び面外振動の加速度を測定した。データ計測のサン プリング周波数は $200 \mathrm{~Hz}$ とし, 常時計測を行った。風向 ならびに風速は, 大型ケーブル模型近傍の北東位置にお ける地表面からの高さ $10 \mathrm{~m}$ の位置に設置された超音波 風向風速計により測定した。なお，風向は真北から時計 回りの角度 $0^{\circ} \sim 360^{\circ}$ で表示している。また, 降雨の有無 については, 近隣の気象台潮岬測候所（標高 $73 \mathrm{~m}$ ）で観 測された， 1 時間ごとの降雨量のデータで判断した。

加速度データから振動振幅を評価するに際には, 卓越 振動数 (固有振動数) 毎に, 対応するモード形状が正弦 波であると仮定して, 最大振幅を算出した。計測機器の 仕様上, 20 分間のデータが 1 セットとなるため, データ の平均化処理は 20 分間平均とした。

\section{3. 観測結果}

以下に, ケーブル模型 $\mathrm{A}$ ならびにケーブル模型 $\mathrm{B}$ に関 する観測結果を示す。また, 図 1, 表 2 に示寸顕著な振 動事例 4 ケースについては, より詳細に報告する。

\section{1 ケーブル模型 $\mathrm{A}$ における観測結果}

2000 年 11 月から 2001 年 2 月の期間におけるケーブル 模型 $\mathrm{A}$ を用いた観測記録から得られた平均風速一平均倍 振幅を図 2 に示寸。面内・面外の 1 次〜3 次モード別の

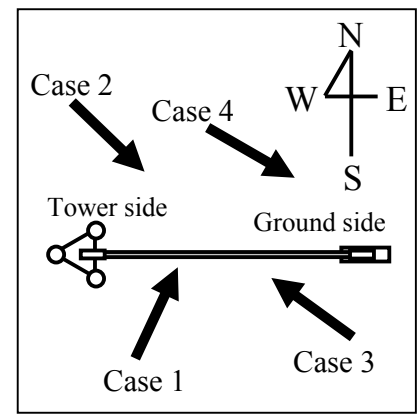

図 1 顕著な振動事例の風向

表 2 顕著な振動事例の気象条件 (20 分間平均値)

\begin{tabular}{|l|c|c|c|c|}
\cline { 2 - 5 } \multicolumn{1}{c|}{} & \multicolumn{2}{c|}{ Cable model type A } & \multicolumn{2}{c|}{ Cable model type B } \\
\cline { 2 - 5 } \multicolumn{1}{c|}{} & Case 1 & Case 2 & Case 3 & Case 4 \\
\hline Mean wind velocity (m/s) & 8.10 & 7.67 & 13.2 & 10.3 \\
\hline Mean wind direction (deg.) & $198.9(\mathrm{SSW})$ & $316.3(\mathrm{NNW})$ & $126.0(\mathrm{SE})$ & $299.5(\mathrm{NW})$ \\
\hline Turbulence intensity $(\%)$ & 40.9 & 30.1 & 40.8 & 46.3 \\
\hline Precipitation $(\mathrm{mm} / \mathrm{h})$ & 34 & 1.5 & 37 & 24 \\
\hline
\end{tabular}



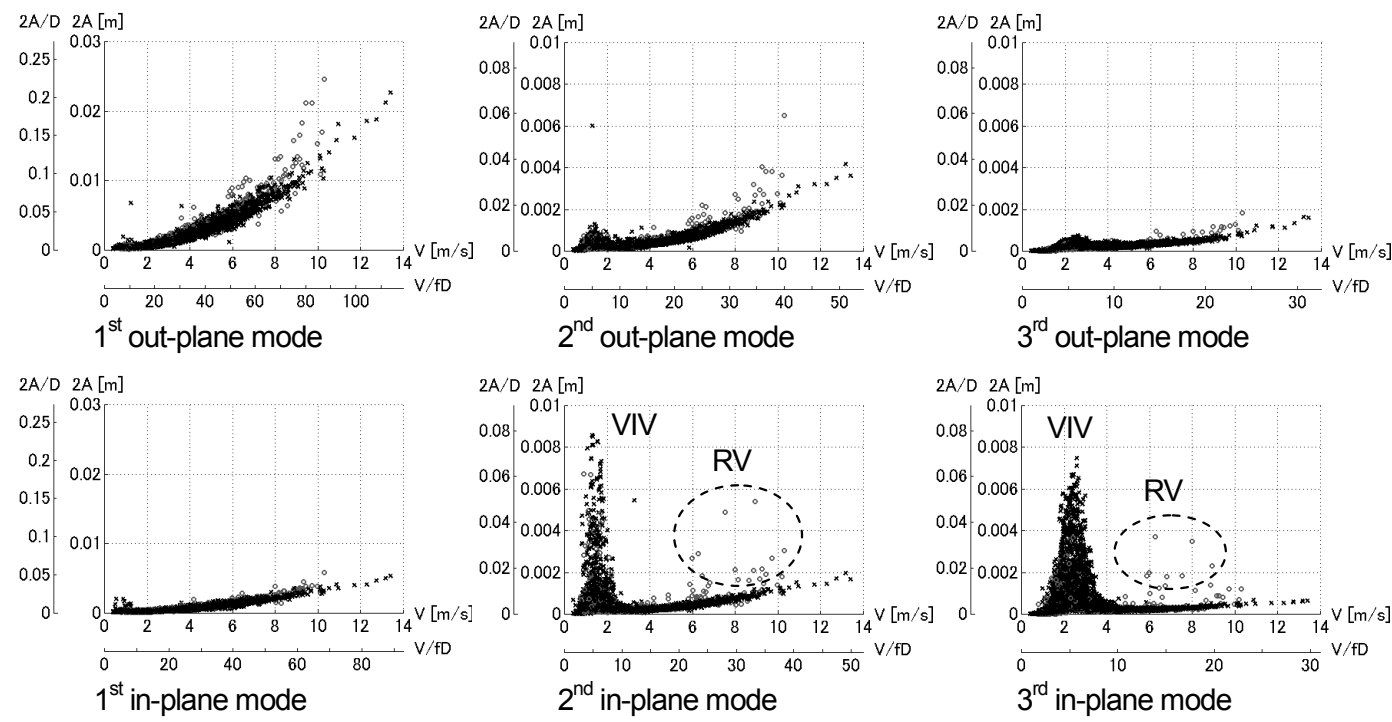

図 2 平均風速一平均倍振幅図 (20 分間平均值, ケーブル模型 $\mathrm{A}$ )

$(\bigcirc$ : 降雨時, $\times$ : 降雨なし, VIV : 渦励振, RV : レインバイブレーション $)$

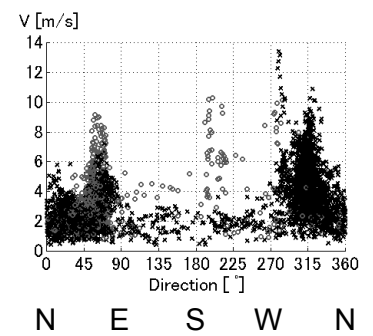

a) Wind direction - velocity

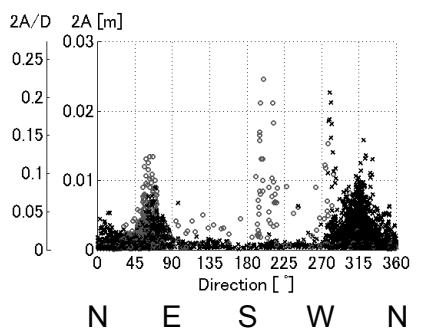

b) $1^{\text {st }}$ out-plane mode

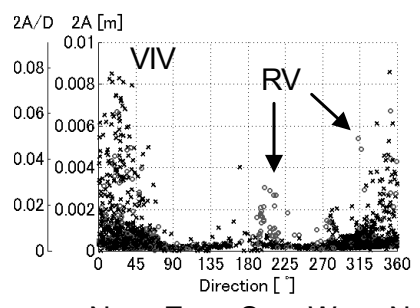

N E S W N

C) $2^{\text {nd }}$ in-plane mode

図 3 風向と風速ならびに応答の関係 (20 分間平均值, ケーブル模型 $\mathrm{A})$

$(\bigcirc$ : 降雨時, $\times$ : 降雨なし, VIV : 渦励振, RV : レインバイブレーション)

応答振幅を観測時の気象データから降雨時と降雨なしに 分けてプロットした。それぞれのプロットは, 20 分間平 均值である。面外 1 次モードでは, バフェッティングと 思われる比較的大きな応答が見られる。また, 面内 2,3 次モードでは, 渦励振が顕著に現れていることが分かる。 さらに全体的傾向として, 降雨時に振幅が大きくなって いる傾向があり, 特に面内 2,3 次モードでは, ある特定 の風速域でその傾向が顕著である。さらに, 図 3 にa)風 向之風速, b)風向と面外 1 次モード応答, $c$ )風向と面内 2 次モード応答の関係を示す (全て平均值)。a) と b) を比較 すると, 両図の形状が似ていることから, 面外 1 次モー ド応答はバフェッティングと考えることができる。また， c)面内 2 次モードの応答図からは, 渦励振が発生してい る風向は, $\mathrm{N}-\mathrm{NNE}$ が卓越しており, ケーブル軸に直交 していることが分かる。一方，前述の降雨時に見られる 風速限定型の応答が発生する際の風向は, SSW もしくは
NW であり，ケーブル姿勢は風向に対して下り勾配とな っている。したがって, これらの応答結果は, レインバ イブレーションである可能性が高いと考えられる。

次に, 表 2 に示したレインバイブレーションと考えら れるケース 1 とケース 2 にいて, より詳細に調べる。 20 分間の平均風速はいずれも $8 \mathrm{~m} / \mathrm{s}$ 程度, 風向は共にケ 一ブル姿勢が下り勾配となる風向であるが，降雨量は大 きく異なり, 気象用語上ケース 1 は「激しい雨」, ケース 2 は「弱雨」となる。まず，ケース 1 において振動が 卓越している面内 3 次モードの時刻歴応答波形, および その振幅が比較的大きい 940 950 秒における面内・面外 3 次モードのリサージュ図, さらには同区間の面内加速 度応答のウェーブレット解析結果を図 4 に示寸。なお, リサージュ図中に示寸実線は, 風向とケーブル軸が作る 面を示し，破線はその直交方向である。また，ケース 2 においても同様に 2 次モードに着目し応答波形を図 5 に 


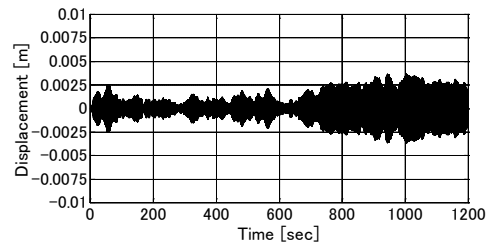

a) Response of $3^{\text {rd }}$ in-plane mode

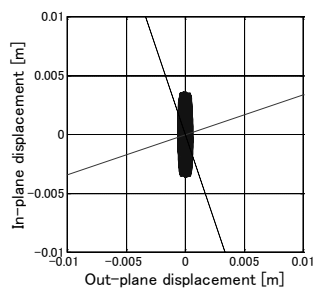

b) Displacement locus of $3^{\text {rd }}$ mode

図 4 ケース 1 の応答性状（ケーブル模型 A)

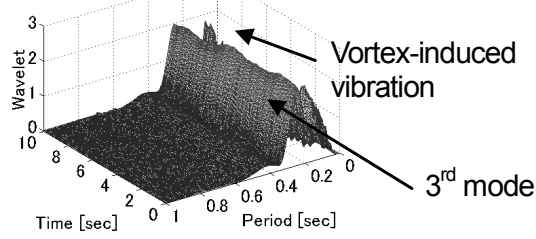

C) Wavelet analysis of in-plane acceleration

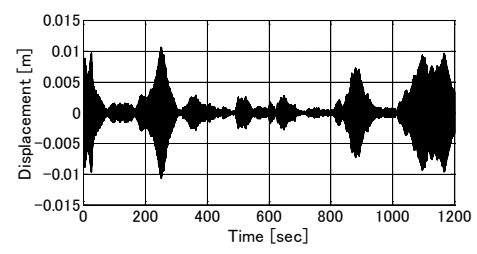

a) Response of $2^{\text {nd }}$ in-plane mode

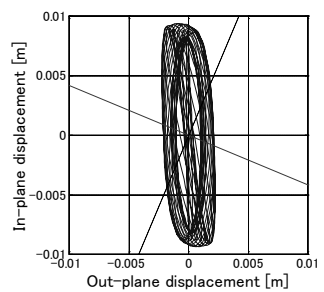

b) Displacement locus of $2^{\text {nd }}$ mode

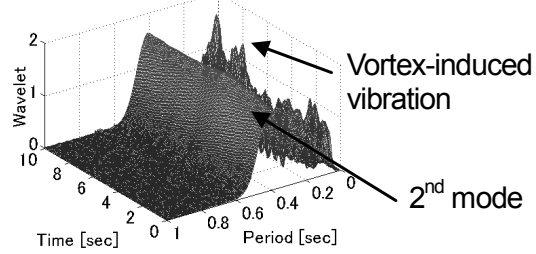

C) Wavelet analysis of in-plane

図 5 ケース 2 の応答性状（ケーブル模型 A) acceleration

示す。ウェーブレット解析とリサージュ図の解析区間は, 1090 1100 秒の 10 秒間である。ウェーブレット解析結 果より, ケース 1 (図 4) では 3 次モード（ $V=7.8 \mathrm{~m}$, $V / f D=17.7)$ ，ケース 2 (図 5) では2 次モード（ $V=7.5 \mathrm{~m}$, $V / f D=27.9)$ に対応する応答はほぼ定常であるが，カルマ ン渦の放出周波数成分が非定常に現れていることが分か る。また, リサージュ図より, 両ケース共, それぞれの 卓越モードで比較的破線に沿った定常的な面内振動であ ることが分かり, 卓越モードの違いはあるものの, 振動 特性は比較的よく似ている。前述の通り, 風向を考える と両ケース共, レインバイブレーションの可能性が高く, ケース 2 のようにわずかな降水量であっても空力的に不 安定化することが分かる。

\section{2 ケーブル模型 B における観測結果}

次に, 2001 年 8 月から 2002 年 3 月及び, 2002 年 8 月 末から 2002 年 9 月までのケーブル模型 B における観測 記録について示す。図 6 に平均風速一平均倍振幅, 図 7 に a)風向之風速, b)風向之面外 1 次モード応答, c)風向 と面外 2 次モード応答の関係を示寸 (全て平均值)。図 6 より, 渦励振は面内方向でよく現れていることが分かる。 また, 前述のケーブル模型 $\mathrm{A}$ のように, 明らかにレイン バイブレーションとわかる降雨時の風速限定型振動は見 られなかった。この理由として,ケーブル模型の構造上, パーツとパーツの間に段差があり, 水路が形成を妨げた 可能性は否定できない。ただし, 高風速域において降雨 ありの状況で振幅が大きい観測記録がいくつか見られる
が,これらのプロットは 2001 年 8 月に付近を通過した台

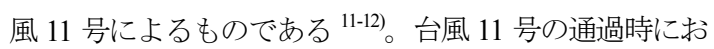
ける風向は $126^{\circ}(\mathrm{SE})$ であり, ケーブル模型が風向に対 して上り勾配であり,「激しい雨」が観測されているが模 型表面に水路は形成されていなかったと考えられ，この 時の振動現象はレインバイブレーションではなかったと 推定される。

そこで, 台風通過時の中で特に大振幅振動が観測され たデータをケース 3 , 別の観測日で平均風速が比較的高 く, 降水量が多い気象条件の下, 風向に対してケーブル が下り勾配となり, レインバイブレーションが発生する 可能性のあるデータをケース 4 とした(図 1 , 表 2 参照)。

ケース 3 につて, 振幅が卓越していると考えられる 面外 1 次モードにおいて振幅が大きくなっている時間帯 (600 秒 800 秒) の 200 秒間における振幅の時刻歴波形 及び，その中でも最大の振幅が得られた時間帯である 680 秒 290 秒の 10 秒間における面内・面外 1 次モード のリサージュ図を図 8 に示す。このときの平均風速は $16.7 \mathrm{~m} / \mathrm{s}$ であり, 無次元風速では $V / f D=133.8$ となる。ま た，リサージュ図を見て分る通り，面内方向にはほとん ど振動していない。風向を考えると, 面内振動が現れて もおかしくはないが, ケーブル模型の構造上, 面内 1 次 モードの構造減衰が他のモードに比べて高いことが影響 しているものと考えられる。さらに, 図 9 に 600 秒 $>00$ 秒における 10 秒平均の風速と乱れ強度を示す。これによ り, 平均風速が大きく, また, 乱れ強度が小さくなった 

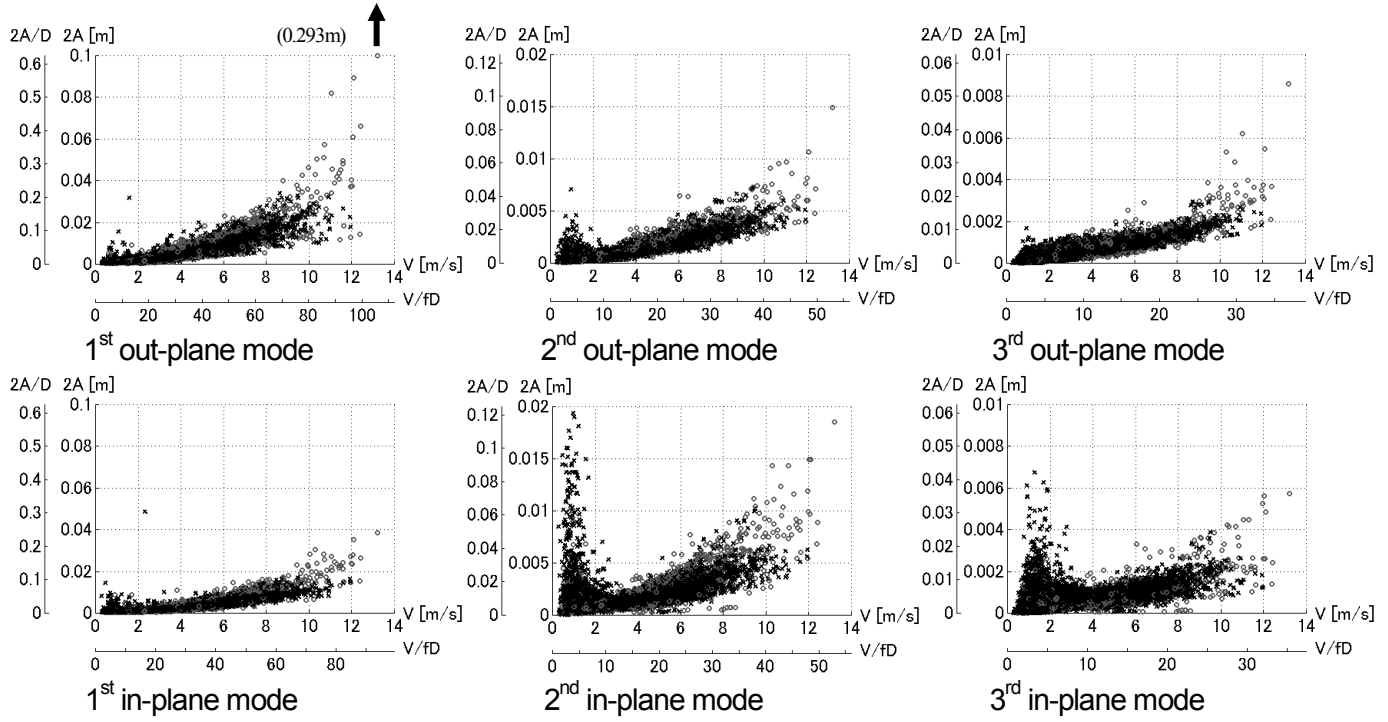

図 6 平均風速一平均倍振幅図 (20 分間平均值，ケーブル模型 $\mathrm{B}, \bigcirc$ : 降雨時, $\times$ : 降雨なし)

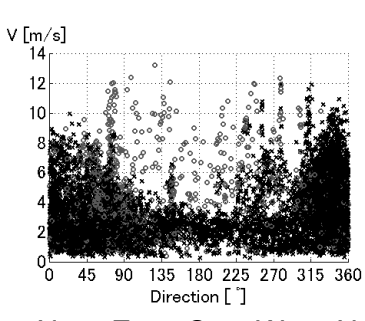

$\mathrm{N} \quad \mathrm{E} \quad \mathrm{S} \quad \mathrm{W} \quad \mathrm{N}$

a) Wind direction - velocity

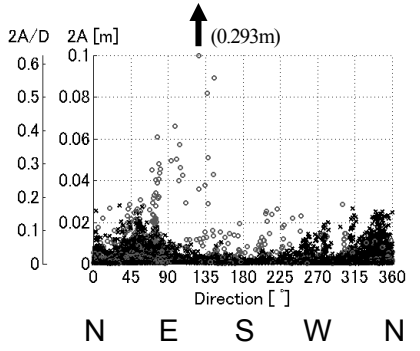

b) $1^{\text {st }}$ out-plane mode

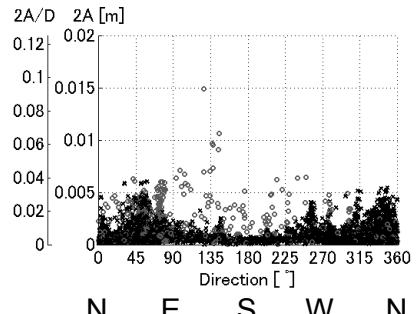

c) $2^{\text {nd }}$ out-plane mode

図 7 風向と風速ならびに応答の関係 $(20$ 分間平均值，ケーブル模型 $\mathrm{B},(\bigcirc:$ 降雨時, $\times$ : 降雨なし)

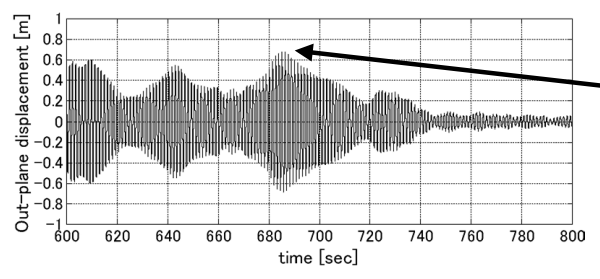

a) Response of $1^{\text {st }}$ out-plane mode

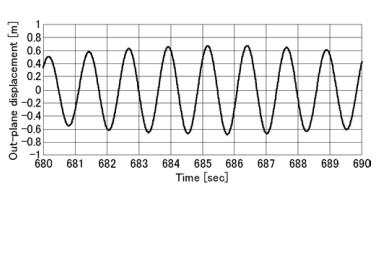

b) Displacement locus of $1^{\text {st }}$ mode

図 8 ケース 3 の応答性状（ケーブル模型 $\mathrm{B}$ )

際に振動振幅が大きくなっていることがわかる。この振 動応答は，別途準定常理論により計算されたバフェッテ イングの応答解析結果よりはるかに大きな振幅で振動し ており, バフェッティングである可能性は小さいと考え られる。より簡単に考察するのであれば, 図7のa)とb) を比較すれば, この大振幅応答が他のバフェッティング 応答と比べて際立って大きいことがわかる。また, 風向 が下り勾配ではなく上り勾配であるため, 水路は形成さ

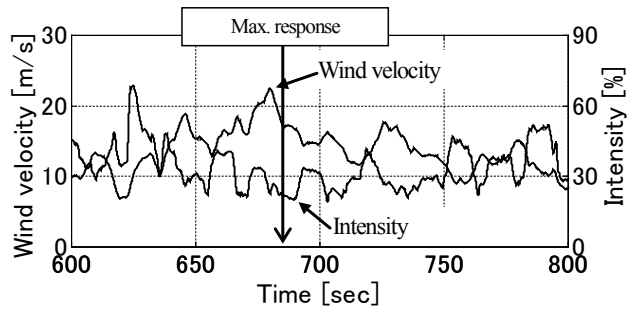

図 9 風速と乱れ強度の関係（10 秒平均） 


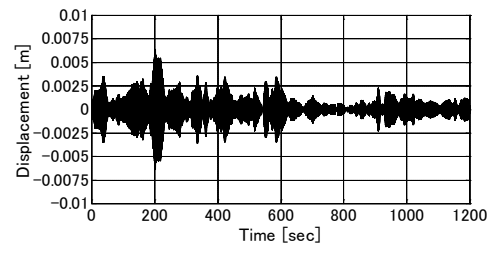

a) Response of $3^{\text {rd }}$ in-plane mode

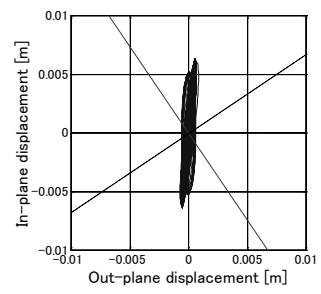

b) Displacement locus of $3^{\text {rd }}$ mode

図 10 ケース 4 の応答性状（ケーブル模型 B

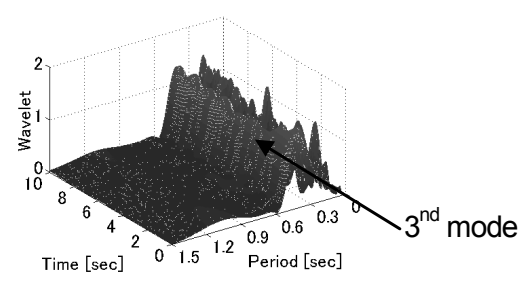

c) Wavelet analysis of in-plane acceleration
れていなかったと推定されるため, レインバイブレーシ ヨンの可能性も小さいと考えられる。従って, 本振動現 象は，ギャロピングである可能性が高いが，一般に強乱 流下においてはギャロッピングの発生は難しいとの報告 もあり ${ }^{15)}$ ，更なる検討を要する。

次にケース 4 につい, 卓越している面内 3 次モード において，振幅の時刻歴波形と最も振幅が大きかった時 間帯である 200 秒〜210 秒の 10 秒間における面内・面外 3 次モードのリサージュ図及び面内加速度応答のウェー ブレット解析結果を図 10 に示す。この卓越周波数から無 次元風速を求めると, $V / f D=33.8$ となる。降雨量が「強い 雨」で比較的多いこと, 水路が形成されやすい風向であ ること, 発散的な振動性状を示していないことなどから レインバイブレーションである可能性が示唆される。

ケーブル模型 B においては, 比較的高風速域でかつ降 水量が多い状態における観測結果が得られたが，風向に 応じてその振動性状は異なり, ギャロッピングと思われ る振動ならびにレインバイブレーションと思われる振動 が観測された。

\section{4.まとめ}

以上の結果をまとめると以下の通りである。

（1）風速・風向が同様であっても, 降雨時に振幅が大 きくなる傾向が見られ，レインバイブレーション と推定される振動現象が観測された。また，降水 量が少なくても風向, 風速の条件によりレインバ イブレーションが発生する可能性が示唆された。

（2）台風の通過時に面外 1 次モードの大振幅振動が観 測された。レインバイブレーションやバフェッテ イングの可能性は小さく, ドライステートギャロ ッピングであった可能性も考えられるが，一般に 強乱流下においてギャロッピングの発生は困難 とも思われ，更なる検討を要する。
謝辞

大型ケーブル模型を用いた屋外観測実験は, 平成 12〜 14 年度日本学術振興会科学研究費補助金 - 基盤研究 (A)(2)（課題番号 : 12305030, 研究代表者 : 松本 勝) に よって実施された。

参考文献

1) Matsumoto, M., Shiraishi, N. and Shirato, H., "Rain-wind induced vibration of cables of cable-stayed bridges", J. Wind Eng. Ind. Aerod., Vol.43, pp.2011-2022, (1992)

2) Cheng, S., Irwin, P.A., Jakobsen, I.B., Lankin, J., Larose, G.L., Savage, M.G., Tanaka, H. and Zurell, C., "Divergent motion of cables exposed to skewed wind", Proc. of the Fifth Int. Symp. on Cable Dynamics, pp.271-278, (2003)

3) Larose, G.L., Jakobsen, J.B. and Savage, M.G, "Wind-tunnel experiments an inclined and yawed stay cable model in the critical Reynolds number range", Proc. of the Fifth Int. Symp. on Cable Dynamics, pp.279-286, (2003)

4) Matsumoto, M., Yagi, T., Hatsuda, H., Shima, T., Tanaka, M. and Naito, H., "Dry galloping characteristics and its mechanism of inclined/yawed cables", J. Wind Eng. Ind. Aerod., Vol. 98, No.6-7, pp.317-327, (2010)

5) Matsumoto, M. and Laneville, A., "Generation of Galloping of Bluff Body in Relation to Karman Vortex", Proc. of the 13th Int. Conf. on Wind Engineering, (2011)

6)樋上 琇一，「斜張橋ケーブルの Rain Vibration」，日 本風工学会誌第 27 号, pp.17-28, (1986)

7) Yoshimura, T., Tanaka, T., Sakai, N. and Higa, S., "Rain-wind induced vibration of the cables of the Aratsu Bridge”, 第 10 回風工学シンポジウム論文集, pp.127-132,(1988)

8）森 喜仁, 石飛 太郎, 南條 正洋, 「天保山大橋のケ 一ブル振動とその対策」, 第 12 回風工学シンポジウ 
ム論文集, pp.273-278, (1992)

9) Matsumoto, M., Yagi, T., Liu, Q., Oishi, T. and Adachi, Y, "Effects of axial flow and Karman vortex interference on dry-state galloping of inclined stay-cables", Proc. of the Sixth Int. Symp. on Cable Dynamics, pp.247-254, (2005)

10) Matsumoto, M., Shirato, H., Yagi, T., Goto, M., Sakai, S. and Ohya, J., "Field observation of the full-scale wind-induced cable vibration", J. Wind Eng. Ind. Aerod., Vol. 91, pp.13-26, (2003)

11) 松本 勝, 白土 博通, 八木 知已, 林 泰一, 酒井 精 一郎, 大谷 純, 岡田 太賀雄, 「屋外大型傾斜ケーブ ル模型を用いた斜張橋ケーブルの空力振動に関す る研究」, 京都大学防災研究所年報, 第 45 号 B-1, pp.399-406, (2002)

12）松本 勝, 白土 博通, 八木 知己, 酒井 精一郎, 大 谷 純, 岡田 太賀雄, 「風洞実験及び屋外動態観測 に基づく傾斜ケーブルの空力振動現象に関する研 究」, 第 17 回風工学シンポジウム論文集, pp369-374, (2002)

13）松本 勝, 白土 博通, 八木 知己, 林 泰一, 酒井 精 一郎, 大谷 純, 岡田 太賀雄, 大石 孝弘, 「屋外観 測および風洞実験による傾斜ケーブルの空力振動 に関する研究」, 京都大学防災研究所年報, 第 46 号 B, pp.319-329, (2003)

14) Matsumoto, M., Yagi, T., Sakai, S., Ohya, J., Okada, T., "Field observations of wind-induced cable vibrations using large-scale inclined cable model", Proc. of the Eleventh Int. Conf. on Wind Engineering, pp.2149-2156, (2003)

15) 松本 勝, 白石 成人, 白土 博通, 平井滋登, 佐野 祐一, 桂 一詞,「斜張橋ケーブルのレインバイブレ ーションの振動性状とそれに及ぼす乱流およびス クルートン数の影響」, 第 11 回風工学シンポジウム 論文集, pp.269-274, (1990) 